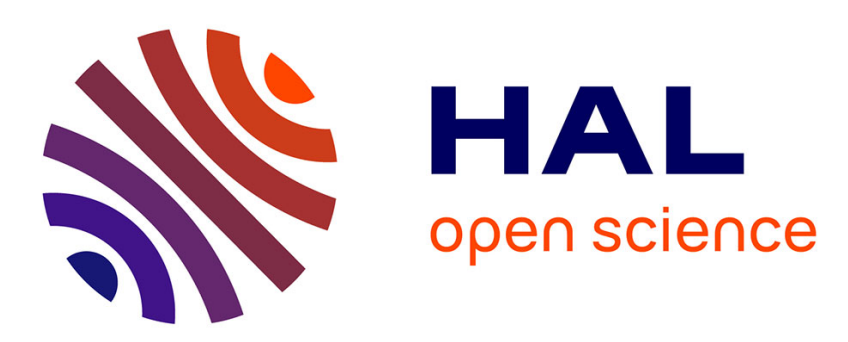

\title{
Irregularities in Scandinavian postglacial uplift/subsidence in time scales tens, hundreds, thousands of years
}

\author{
Søren Gregersen, Peter Voss
}

\section{- To cite this version:}

Søren Gregersen, Peter Voss. Irregularities in Scandinavian postglacial uplift/subsidence in time scales tens, hundreds, thousands of years. Journal of Geodynamics, 2010, 50 (1), pp.27. 10.1016/j.jog.2009.11.004 . hal-00634695

\section{HAL Id: hal-00634695 \\ https://hal.science/hal-00634695}

Submitted on 22 Oct 2011

HAL is a multi-disciplinary open access archive for the deposit and dissemination of scientific research documents, whether they are published or not. The documents may come from teaching and research institutions in France or abroad, or from public or private research centers.
L'archive ouverte pluridisciplinaire HAL, est destinée au dépôt et à la diffusion de documents scientifiques de niveau recherche, publiés ou non, émanant des établissements d'enseignement et de recherche français ou étrangers, des laboratoires publics ou privés. 


\section{Accepted Manuscript}

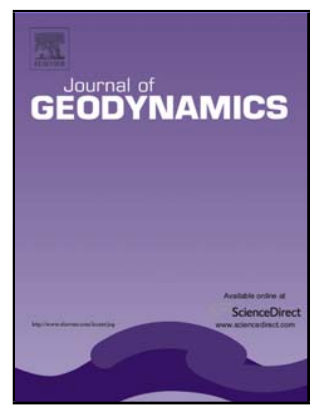

Title: Irregularities in Scandinavian postglacial uplift/subsidence in time scales tens, hundreds, thousands of years

Authors: Søren Gregersen, Peter Voss

S0264-3707(09)00160-4

PII: doi:10.1016/j.jog.2009.11.004

DOI: GEOD 953

To appear in: $\quad$ Journal of Geodynamics

Received date: $\quad 31-10-2008$

Revised date: $\quad 21-8-2009$

Accepted date: $\quad$ 16-11-2009

Please cite this article as: Gregersen, S., Irregularities in Scandinavian postglacial uplift/subsidence in time scales tens, hundreds, thousands of years, Journal of Geodynamics (2008), doi:10.1016/j.jog.2009.11.004

This is a PDF file of an unedited manuscript that has been accepted for publication. As a service to our customers we are providing this early version of the manuscript. The manuscript will undergo copyediting, typesetting, and review of the resulting proof before it is published in its final form. Please note that during the production process errors may be discovered which could affect the content, and all legal disclaimers that apply to the journal pertain. 


\title{
Irregularities in Scandinavian postglacial uplift/subsidence in time scales tens, hundreds, thousands of years.
}

Søren Gregersen and Peter Voss, Geological Survey of Denmark and Greenland, Ostervoldgade 10, DK-1350 Copenhagen K, Denmark, sg@geus.dk and pv@geus.dk.

\begin{abstract}
Discussions continue on uplift/subsidence in Denmark/southern Scandinavia. The patterns in time scales of 10s, 100s and 1000s of years show some similarities and some differences. Geodetic observations exist for all of Scandinavia. Those describe the phenomenon in 10s - 100s of years scale. Earthquake observations in seismology are of relevance to the same time scales. Geological studies of dated shore lines describe the postglacial earth-surface motion in a quite different time scale of $100 \mathrm{~s}-1000 \mathrm{~s}$ of years. There is a need for integration of these observations geographically. Present integration of the data of various time scales is that the overall uplift pattern of all time scales 10s, 100s, 1000s and 10,000 years are coincident. But a few geodynamics irregularities are found. Further observations in the various time scales will be collected together with process descriptions of the observed similarities and differences in the DynaQlim project.
\end{abstract}

\section{Introduction}

Our geodesist colleagues are making more and more definitive observations of the uplift pattern of Scandinavia and the surrounding subsidence. Methods are improving from levelling and sea level observations, where observations improved as period of observation grew from tens of years to more than hundred years, to GPS measurements nowadays. Many of the DynaQlim papers of this volume present the good modern picture of these time scales. Such a good reference pattern NKG2005LU (Vestøl, 2006; Ågren and Svensson, 2007; Engsager et al. 2006, personal communication) is in the present paper displayed together with the longer term geological pattern of thousands of years. The latter gives the pattern of motion since the Ice Age, i.e. approx. 10,000 years. The comparison of the two patterns is seen in Figure 1. The differences in the broad scale picture are obviously small. This emphasizes that it is the same phenomenon which uplifts Scandinavia in the time scales tens, hundreds and thousands of years.

The first irregularity to be noticed is that the uplift rate has changed drastically from very fast right after the Ice Age to much slower nowadays.

\section{Stresses in the lithosphere of various time scales}

For a description of the stresses in the Scandinavian lithosphere the uplift pattern may well be of some significance. But from a point of view of seismology, which can give information of the same short time scales as the geodetic observations, the uplift is one factor of several, which are dominated by the stresses caused by the present lithospheric plate movements (Gregersen and Voss, 2009; Olesen et al. 2004; Bungum et al. 1991; Lindholm et al. 2000; Gregersen, 1992). The earthquake geography in Scandinavia is displayed in Figure 2. Like displays of earthquake activity in other parts of the world it does not matter much which is the time period displayed. The general 
pattern is the same in any time period, while small details can be different. The figure shows that the earthquake activity is most concentrated along the Norwegian coast and continental margin, along the Swedish east coast, and in and around the Oslo Fjord. It is well established that the earthquake activity in Denmark is the southern limitation of the Scandinavian seismicity (Gregersen et al., 1998). And there are no recent earthquakes in Jylland in the middle of Denmark. It is also established with good credibility that the earthquake activity is smaller in northern Germany, in Poland and in the Baltic states (e.g. Grünthal et al, 2008). In the latter areas the seismograph coverage has until recently been significantly poorer, so the information in the map is influenced by less sensitivity to small earthquakes. But there is not much doubt that the Kaliningrad events in 2004 of magnitudes just over 5 are very unusual for the coast of Poland, Russia and Lithuania (Gregersen et al. 2007). The map should be complete down to magnitude 4.

Also shown in Figure 2 are short heavy lines in northern Norway, Sweden and Finland. These show the locations of large postglacial faults, which are convincingly argued to be developed in large earthquakes (e.g. Lagerbäck, 1991; Olesen, 1991; Olesen et al. 2004). The dating of these earthquakes is very accurate via disturbances of sediments in liquefaction, and counting of varve layers. Coincident with the liquefaction phenomena are large landslides, which support the interpretation of these large faults as signs of earthquakes 9,000 years ago.

The central part of the postglacial uplift area is indicated in Figure 2 for comparison to the earthquake pattern. We have in several papers argued that there is no correlation between the uplift pattern and the earthquake geography (Gregersen, 2002; Gregersen and Voss, 2009). In those papers we have argued that the stresses have changed drastically during the 10,000 years of these investigated phenomena. Right after the Ice Age the uplift was dominating, while now the plate motions in plate tectonics sense are dominating. This is demonstrated by the lack of correlation of the seismicity and the uplift pattern. And it is confirmed by the overwhelming regularity of the compressional orientations of focal mechanisms in the area (Fig. 3) as well as other data of the World Stress Map Project (Zoback et al. 1989, 1992; Zoback 1992; Poutanen et al., 2009). Northwest - southeast compression is dominating, along the absolute lithosphere plate motions, although also many other scattered compression orientations are found. We note that the same conclusion of change of dominating stress is emphasized also by Mörner (2003) with overlapping as well as different arguments.

\section{Uplift pattern and irregularities}

Going into the description of the general uplift pattern are the works of many scientists over the years (e.g. Mertz, 1924 and Paasse, 1996). The geological uplift pattern in Figure 1 is a generalisation of all of these investigations (Mörner, 2003). When one looks at a smaller area (Fig. 4) one finds more irregularities in the curves, even if these are also generalized and smoothed. With small kinks in the regional pattern it is seen that a very consistent pattern is revealed. Various claims of irregularities have been postulated though, in the points of Figure 4 marked by circles. Geological signs of motion, which have been promoted, are the following:

Læsø, Denmark. Hansen (1994) has investigated sand deposits of ages less than 10,000 years in Læs $\varnothing$ and found indications of a large fault of displacement 4 meters. No other indicators of earthquakes have been identified. So it can not be distinguished whether this fault developed as an earthquake of any regional significance, a sediment slide or just a slow motion displacement. As seen in Figure 4 the uplift of the island Læsø fits exactly the 12 meters in the regional pattern. That 
the island of Læsø should have subsided 4 meters and then uplifted the same number of meters within several thousands of years seems improbable. More supporting evidence is necessary to substantiate the claim of an earthquake 4-5,000 years ago in Læs $\varnothing$.

West coast of Sweden and Northern Sweden. Other claims of irregularities have been presented by Mörner (2003). Several locations on the Swedish west coast have been pointed out. The signs of geological movement are faults and rock deformation in a few cases, and in many incidences rock slides and liquefaction in several stratigraphic layers. In several places have been observed sediment deformations and in some also signs of tsunami disturbances of the sediments. Drastic coincident deformations are demonstrated in Mörners (2003) paper. The evidence is not as overwhelming as in northern Sweden in the layers from the end of the Ice Age (e.g. Lagerbäck, 1991), but it could be that some irregularities in the pattern of Figure 4 are in accord with Mörners (2003) observations. The present paper just points to the possibility of earthquakes and irregularities near the coast of southwestern Sweden.

North Jylland, Denmark. In the recent paper by Sørensen et al. (2009) it is indicated that the northern grouping of the earthquakes in the Skagerrak between Norway and Denmark (Fig. 2) is happening in the Tornquist Zone, which is one of the most significant geological lineaments in Scandinavia (e.g. Gregersen et al. 2006 and 2009). Also further southeast the Tornquist Zone is delineated by small earthquakes (Fig. 2) (Gregersen et al. 1998; Jensen et al. 2002). In the middle of Denmark, in the area around the road Hobro - Aalborg - Frederikshavn (Fig. 5) no earthquakes have been found. And this has given rise to previous statements (e.g. Gregersen et al. 1998) that this part of the Tornquist Zone is not active. Recent geological as well as geodetic investigations modify this by what is presented in Figure 5. Here is presented a bend in the uplift pattern in all investigated time scales from 10 s to 10,000 s of years. This bend is a description of observations which south of Aalborg show a trend of uplift as a stiff plate with a constant gradient, and another gradient, i.e. another stiff plate uplift north of Aalborg. The bend is just where earthquakes are missing, so we tend to describe this bending as a creep phenomenon. In Skåne, southern Sweden repeated GPS measurements by Pan et al. (1999) have indicated differences on the two sides of the Tornquist Zone.

Rügen, Germany. And this bending phenomenon in the middle of Denmark does not stand alone. When the evidence was presented recently in a conference, the authors have been told of a similar observation by Dietrich (personal communication, 2008) of a systematic, and repeated change in trend in geodetic levelling in the island of Rügen in northern Germany. The location is marked in Figure 5 by a circle. These are the kinds of observations we seek in Project DynaQlim.

Karelia, Russia. Many faults in Karelia have been interpreted as postglacial earthquakes, with supporting evidence in rockfalls/landslides (Lukashov 1995).

\section{Resulting status is:}

Overall coincident uplift pattern of all time scales $10 \mathrm{~s}, 100 \mathrm{~s}, 1000 \mathrm{~s}$ and 10,000 years confirmed in Scandinavia.

Some geodynamics irregularities found. They may be connected to earthquakes or to slower creep. Hopefully more is to be disclosed in Project DynaQlim by further investigations.

\section{And some of the irregularities are seriously doubtful.}




\section{Acknowledgments}

Many students have over the years contributed to the computation of the Danish earthquake locations. Our colleague H.P. Rasmussen has made many of the P and S arrival readings.

\section{References}

Bedsted Andersen, O., Kejlsø, E. and Remmer, O. 1974. Secular movements within Jutland as determined from repeated precise levellings 1885-94 and 1943-53. Geodætisk Instituts Skrifter $3^{\text {rd }}$ row, volume 40 .

Bungum, H., Alsaker, A., Kvamme, L.B. and Hansen, R.A. 1991. Seismicity and seismotectonics of Norway and nearby continental shelf areas. Journal of Geophysical Research, 96, 2249-2265.

Christensen, C. 2001. Coastal settlement and sea level change in the Stone Age. In Jensen, O.L., Soerensen, S.A. and Hansen, K.M. (eds.) Denmarks Hunting Stone Age - status and perspectives. Hoersholm Egns Museum 2001, 183-193.

Gregersen, S. 1992: Crustal stress regime in Fennoscandia from focal mechanisms. Journal of Geophysical Research 97, 11821-11827.

Gregersen, S. 2002: Earthquakes and change of stress since the ice age in Scandinavia. Bulletin of the Geological Society of Denmark 49, 73-78.

Gregersen, S., Hjelme, J. \& Hjortenberg, E. 1998: Earthquakes in Denmark. Bulletin of the Geological Society of Denmark 44, 115-127.

Gregersen, S. and Schmidt, K. 2001. Tectonics in Denmark - the Sorgenfrei-Tornquist Zone (in Danish). Geologisk Nyt, 1, FEB 2001.

Gregersen, S., Voss, P., Shomali, Z.H., Grad, M., Roberts, R.G. \& Tor Working Group 2006: Physical differences in the deep lithosphere of Northern and Central Europe. In Gee, D.G. \& Stephensson, R.A. (eds.) European Lithosphere Dynamics. Memoirs of the Geological Society of London 32, 313-322.

Gregersen, S., Wiejacz, P., W. Dębski, B. Domanski, B. Assinovskaya, B. Guterch, P. Mäntyniemi, G. Nikulin, A. Pacesa, V. Puura, A.G. Aronov, T.I. Aronova, G. Grünthal, E.S. Husebye, and S. Sliaupa, 2007. The exceptional earthquakes in Kaliningrad District, Russia on September 21, 2004. Physics of the Earth and Planetary Interiors 164, 63-74.

Gregersen, S. and Voss, P. 2009. Stress change over short geological time: case of Scandinavia over 9,000 years since the Ice Age. In Reicherter, K., Michetti, A.M. and Silva Barroso, P.G. (eds.) Paleoseismology: Historical and prehistorical records of earthquake ground effects for seismic 
hazard assessment. Geological Society of London, Special Publications 316,173-178, DOI: 10.1144/SP316.10.

Gregersen, S., Voss, P., Nielsen, L.V., Achauer, U., Busche, H., Rabbbel, W., Shomali, Z.H. 2009. Uniqueness of modelling results from teleseismic P-wave tomography in Project Tor. Tectonophysics, doi: 10.1016/j.tecto.2009.01.020.

Grünthal, G., Stromeyer, D., Wylegalla, K., Kind, R., Wahlström, R., Yuan, X., and Bock, G. 2008. The Mw $3.1-4.7$ earthquakes in the southern Baltic Sea and adjacent areas in 2000, 2001 and 2004. Journal of Seismology, DOI 10.1007/s10950-008-9096-0.

Hansen, J.M. 1994. Læsø's evolution and landscapes - about the island that rocks and jumps (in Danish). Danish Geological Survey, Geografforlaget, Brenderup, Denmark, 55 pp.

Jensen, J.B., Petersen, K.S., Konradi, P., Kuijpers, A, Bennike, O., Lemke, W. and Endler, R. 2002. Neotectonics, sea-level changes and biological evolution in the Fennoscandian Border Zone of the southern Kattegat Sea. Boreas, 31, 133-150.

Lagerbäck, K. 1991. Seismically deformed sediments in the Lansjärv area, northern Sweden. SKB Technical Report 91-17. Svensk Kärnbränslehandtering AB, Stockholm, Sweden, pp. 58.

Lindholm, C.D., Bungum, H., Hicks, E. and Villagran, M. 2000. Crustal stress and tectonics in Norwegian regions determined from earthquake focal mechanisms. Geol. Soc. London 167, 429439.

Lukashov, A.D. 1995. Paleoseismotectonics in the northern part of Lake Onega (Zaonezhskij Peninsula, Russian Karelia). Geological Survey of Finland, report YST-90.

Lykke-Andersen, H. and Borre, K. 2000. Active Tectonics in Denmark - there is life in the Sorgenfrei-Tornquist Zone (in Denmark). Geologisk Nyt, 6, DEC 2000.

Mertz, E.L. 1924. Late and post-glacial height changes in Denmark (in Danish). Danish Geological Survey (DGU) 2. raekke nr. 41. pp. 50.

Mörner, N.A. 2003. Paleoseismicity of Sweden. A novel paradigm. JOFO Grafiska AB, Stockholm.

Olesen, O. 1991. A geophysical investigation of the relationship between old fault structures and postglacial faults in Finnmark, northern Norway. Ph. D. thesis, Technical University of Trondheim, Norway, pp.126.

Olesen, O., Blikra, L.H., Braathen, A., Dehls, J.F., Olsen, L., Rise, L., Roberts, D., Riis, F., Faleide, J.I. and Anda, E. 2004. Neotectonic deformation in Norway and its implications: a review. Norwegian Journal of Geology, 84, 3-34.

Pan, M., Sjöberg, L.E., Talbot, C. and Asenjo, E. 1999. GPS measurements of crustal deformation in Skåne, Sweden between 1989 and 1996. Geofys. Fören. Forhandl. 121, 67-72. 
Poutanen, M., Dransch, D., Gregersen, S., Haubrock, S., Ivins, E.R., Klemann, V., Kozlovskaya, E., Kukkonen, I., Lund, B., Lunkka, J.-P., Milne, G., Müller, J., Pascal, C., Pettersen, B.-R., Scherneck, H.-G., Steffen, H., Vermeersen, B., Wolf, D. 2009. DynaQlim - Upper mantle dynamics and Quaternary climate in cratonic areas. In Cloetingh, S. and Negendank, J. (eds.). New Frontiers in Integrated Solid Earth Sciences. Springer Verlag. In print.

Paasse, T. 1996. A mathematical model of the shore level displacement in Fennoscandia. Swedish Nuclear Waste management Company (SKB) Technical report 96-24, Stockholm Sweden, pp. 92.

Sørensen, M., Voss, P., Havskov, J. and Gregersen, S., 2009. Earthquakes in Skagerrak between Norway and Denmark. In preparation.

Vestø1, O. 2006. Determination of postglacial land uplift in Fennoscandia from levelling, tideguages and continuous GPS stations using least squares collocation. J.Geodynamics 80, 248-258. DOI 10.1007/s00190-006-0063-7.

Zoback, M.L., Zoback, M.D., Adams, J., Assumpcao, M., Bell, S., Bergmann, E.A., Bluemling, P., Brereton, N.R., Denham, D., Ding, J., Fuchs, K., Gay, N., Gregersen, S., Gupta, H.K., Gvishiani, A., Jacob, K., Klein, R., Knoll, P., Magee, M., Mercier, J.L., Müller, B.C., Paquin, C., Rajendran, K., Stephansson, O., Suarez, G., Suter, M., Udias, A., Xu, Z.H. \& Zhizhin, M. 1989: Global patterns of tectonic stress. Nature 341, 291-298.

Zoback, M.L., 1992. First and second-order patterns of stress in the lithosphere: The World Stress Map Project. J. Geophys. Res., 97, 11,703-11,728.

Ågren, J. and Svensson, R., 2007. Postglacial Land Uplift Model and System Definition for the new Swedish Height System RH 2000.Reports in Geodesy and Geographical Information System Rapportserie, LMV-Rapport 2007:4, Lantmäteriet, Gävle, Sweden.

\section{Figure captions}

Figure 1. Uplift pattern and surrounding subsidence of time scales 10 - 100 years from geodesy observations (Vestøl, 2006; Ågren and Svensson, 2007; K. Engsager, 2007, personal communication) and on time scales 100 - 1,000 - 10,000 years (generalized by Mörner (2003)). The geodetic curves, black, are in millimeters per year. The geological curves red, show hundreds of meters since the Ice Age.

Figure 2. Map of the earthquake geography in Scandinavia covering the years from JAN 1970 to DEC 2004. Earthquakes in the Danish area are extracted from the GEUS earthquake catalogue and earthquakes located outside this area are extracted from the Scandinavian catalogue from Helsinki University. The earthquake magnitude scale is given in the upper left corner. Very thick black lines show the large postglacial faults of age close to 9.000 years (Lagerbäck, 1991. Updated earthquake files for Denmark are available in home page www.geus.dk under seismology, and for the rest of Scandinavia in home page www.seismo.helsinki.fi. From Gregersen and Voss (2009).

Figure 3. Earthquake focal mechanisms in Scandinavia. 
Figure 4. Geological/archeological uplift pattern of the southwestern part of Scandinavia, Denmark - Sweden from Christensen (2001). Full lines as well as interpolated dashed and dotted lines show uplift in meters since last flooding after the Ice Age. Dates when these lines were at sea level are given BC, before Christ. With open circles at Læs $\emptyset$, Rügen and in southern Sweden are marked locations which are specifically mentioned in the text on irregularities. The map is based on more limited maps of Mertz (1924) and Paasse (1996) as well as dating by Christensen (2001). The Hobro- Aalborg-Frederikshavn line shows the location of the diagrams in Figure 5.

Figure 5. The 2 upper diagrams show uplift of late glacial and post glacial shore lines. Data from Mertz (1924) extracted by Lykke-Andersen and Borre (2000)). The geodetic curve 1890 - 1950 was also extracted by Lykke-Andersen and Borre, here based on Bedsted Andersen et al. (1974). The curve 1890 - 1990 is from Gregersen and Schmidt (2001) based on the newest available data. Note the coincident bend in all the curves around Aalborg. 


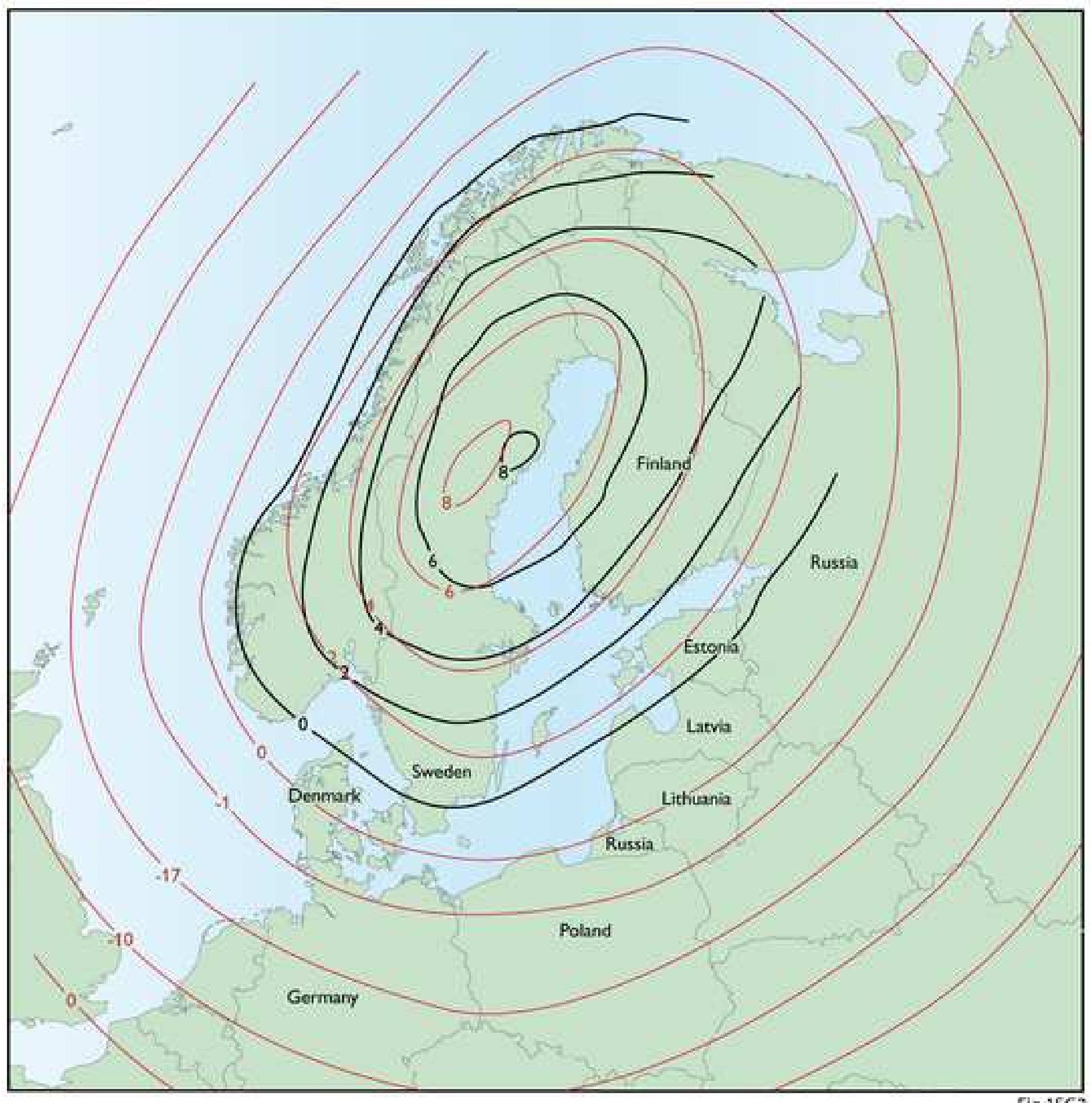

Page 8 of 12 


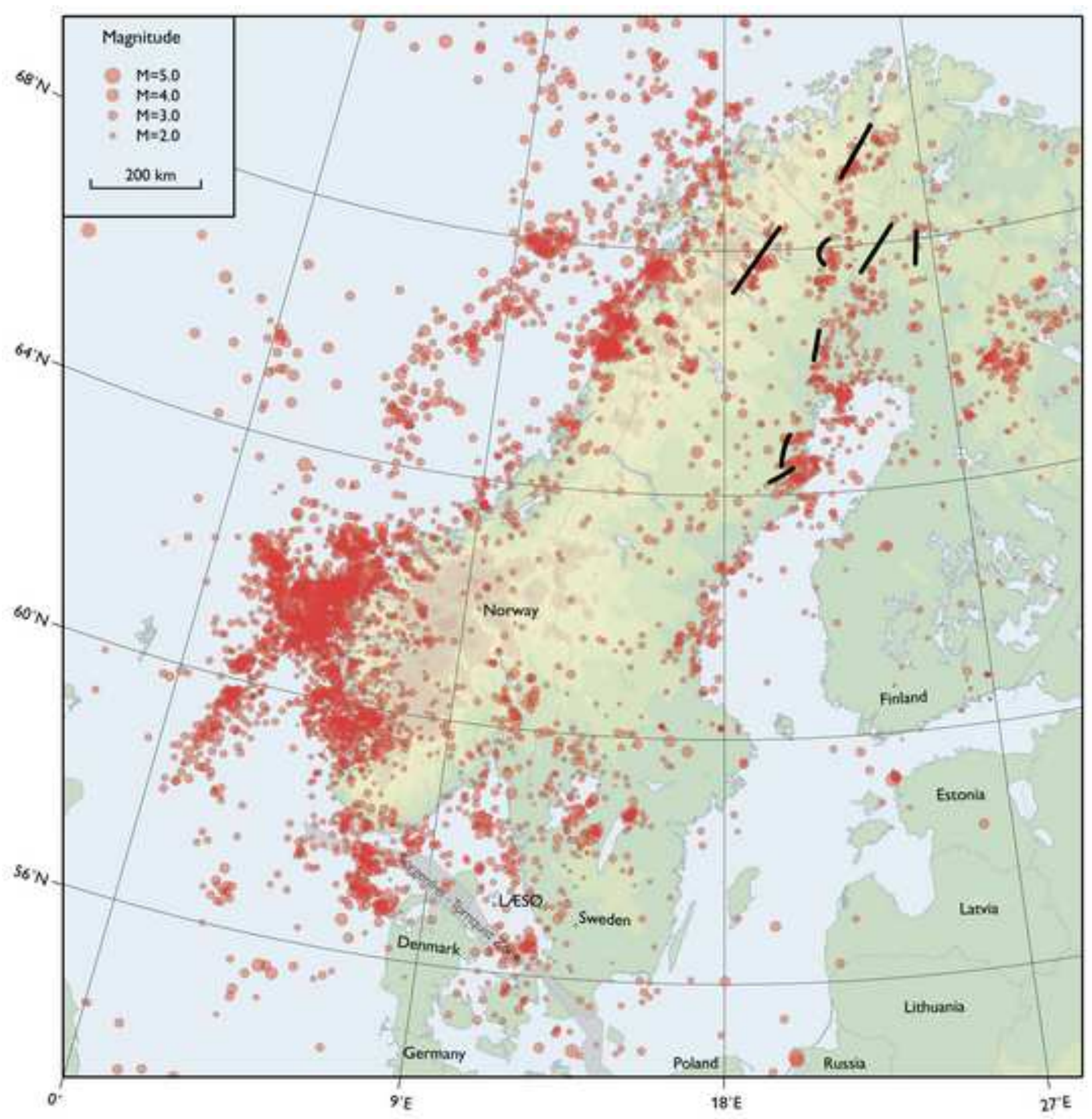




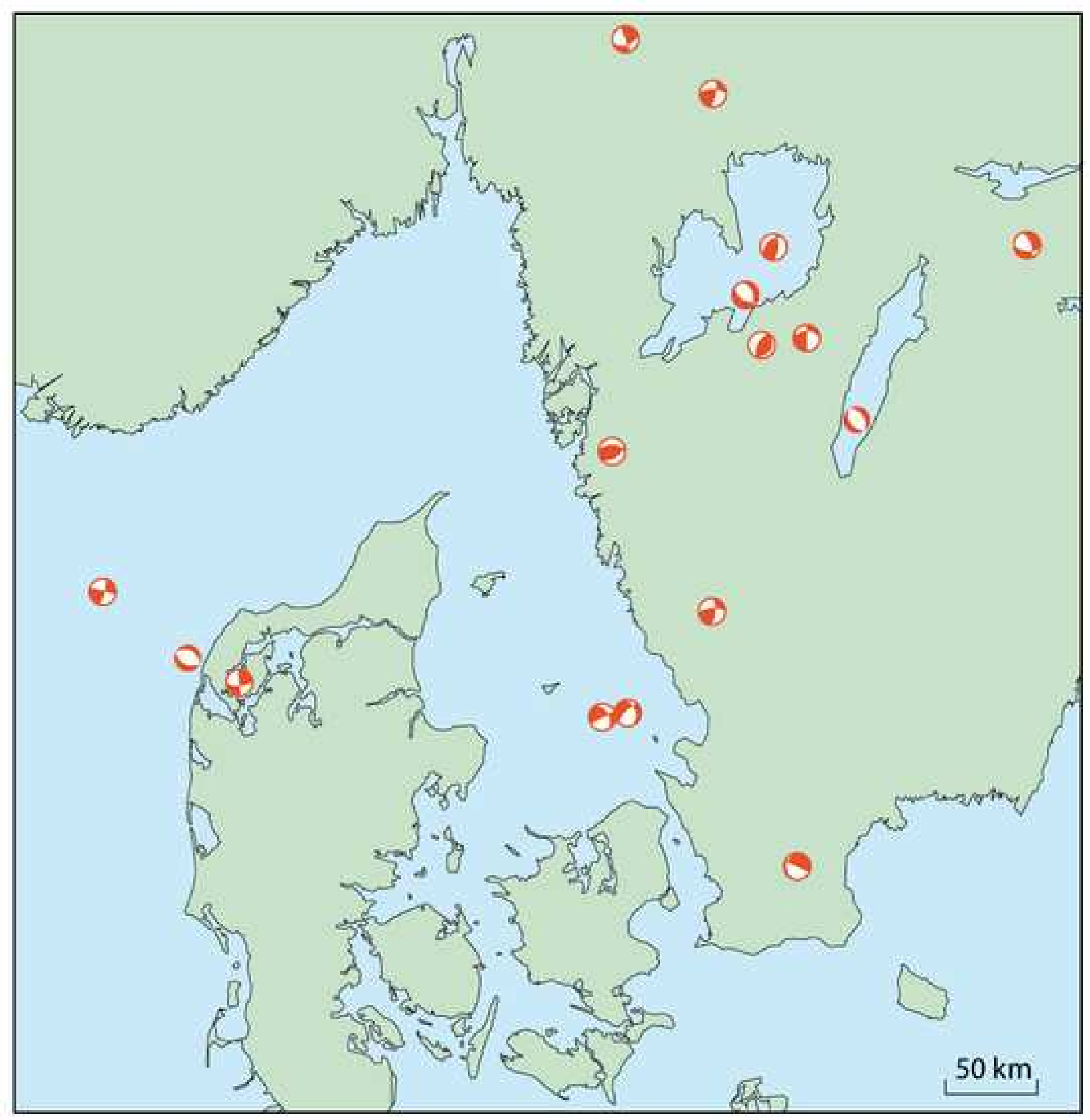

Fig.3_SG2 28-10-08 


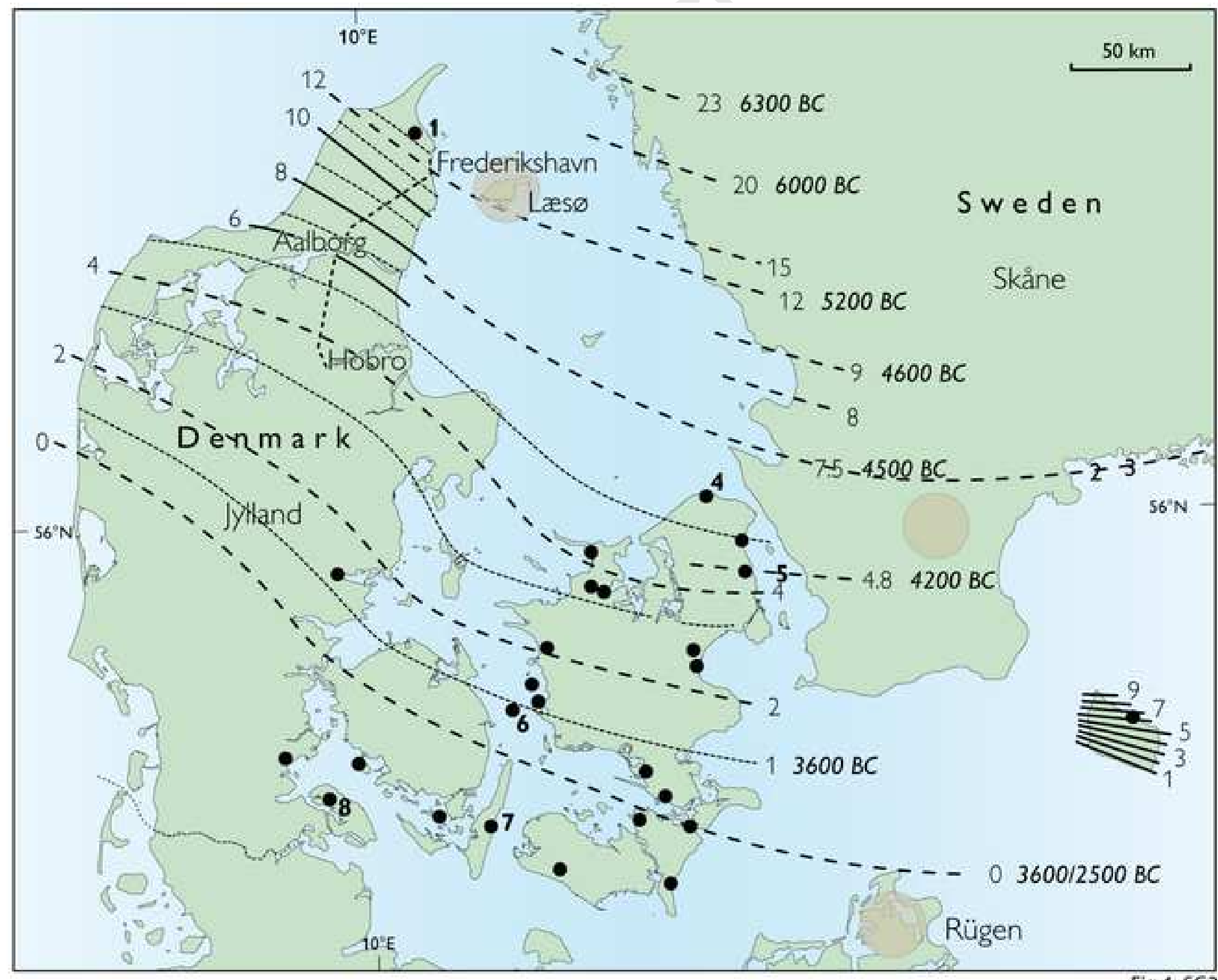

rage 11 or 12 

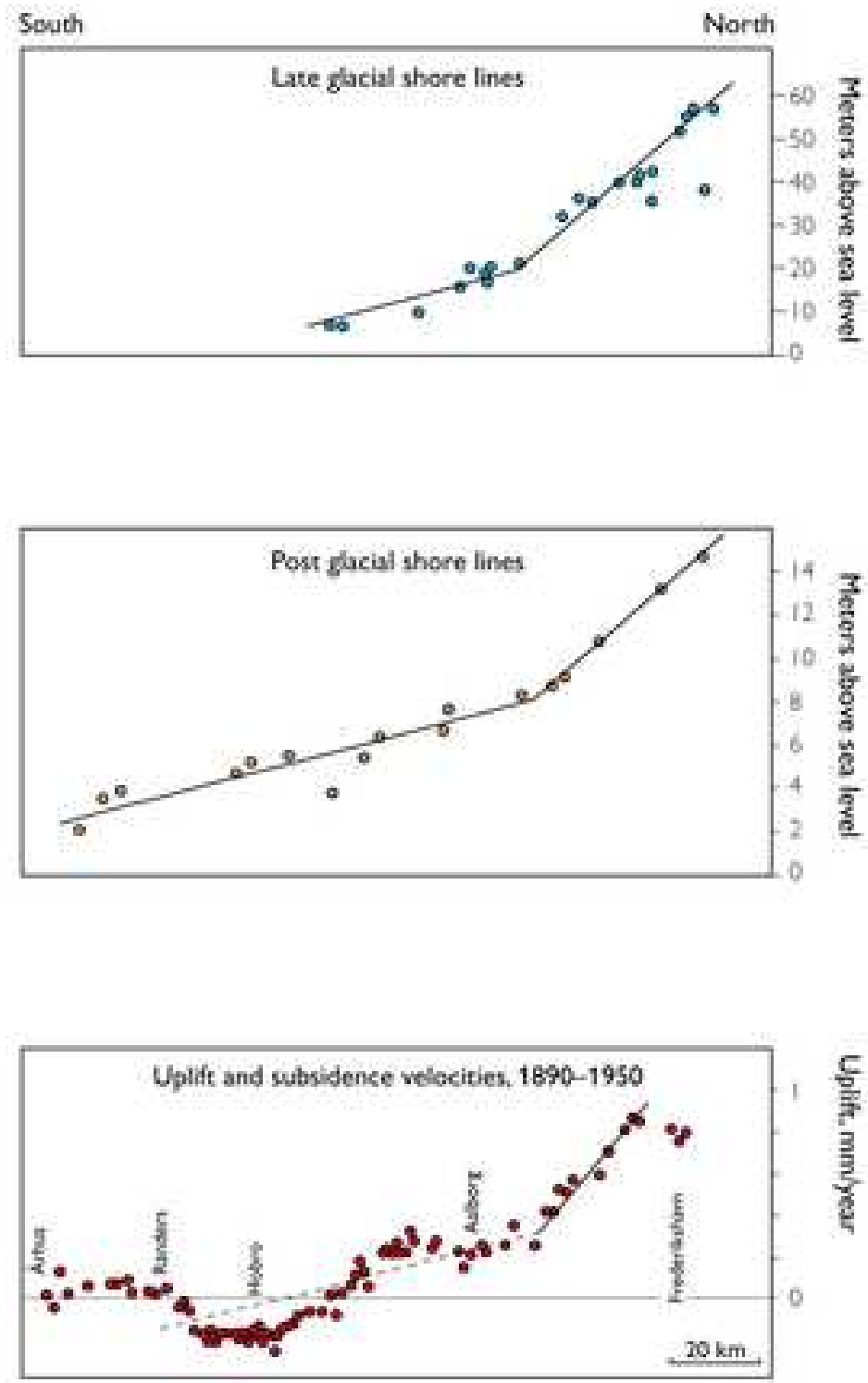

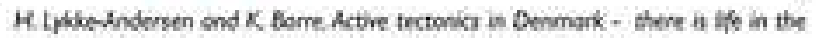
Sorgenfre-tompuit Zone in Damhl). Gedogisk Nyt 6. DEC 2000.

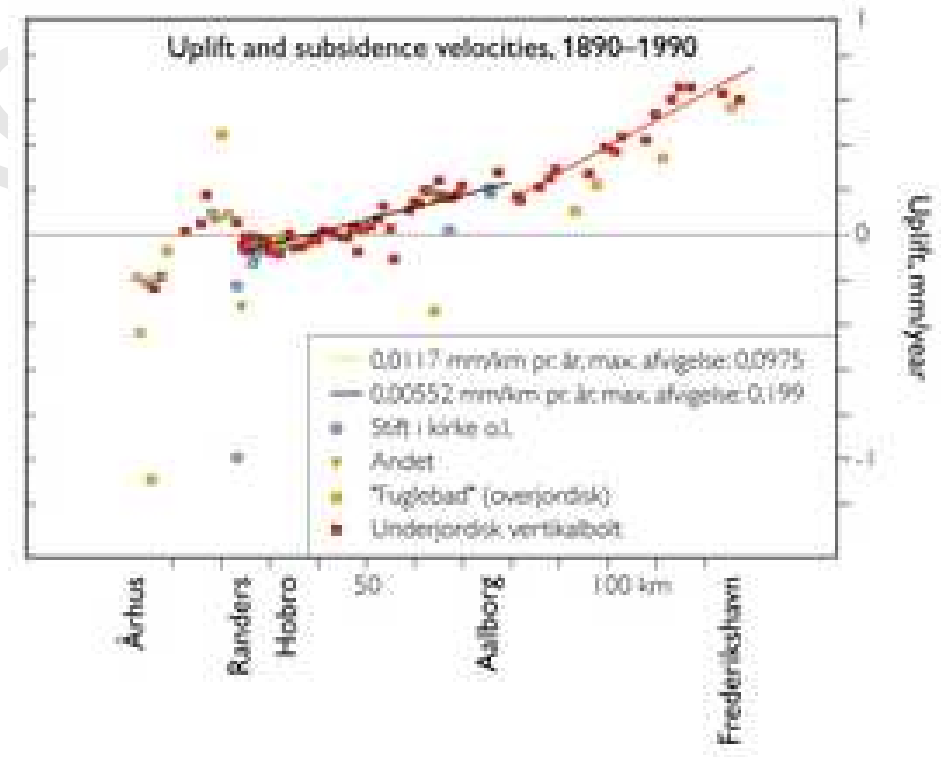

